The

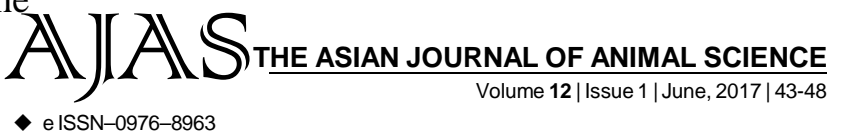

DOI : 10.15740/HAS/TAJAS/12.1/43-48

Visit us | www.researchjournal.co.in

RESEARCH ARTICLE........

\title{
Poultry farming : Suitable intervention for livelihood support and nutritional security of marginal/small farmers of N-E Karnataka
}

\author{
S.N. VINODAKUMAR AND B. K. DESAI \\ .
}

Author for Corresponding -

\section{S.N. VINODAKUMAR}

Department of Agronomy, University of Agricultural Sciences, RAICHUR (KARNATAKA) INDIA Email: vin3234@rediffmail.com vin3234@gmail.com

See end of the article for

Coopted authors'

\begin{abstract}
Backyard poultry farming is a social phenomenon rather than an economic proposition. It is popular among the communities who have no inhibition against keeping birds, eating eggs produced and the meat. Keeping the importance of backyard poultry system in rural areas the present study was undertaken to compare free range/ backyard poultry rearing practices with battery cage rearing in Main Agricultural Research Station (MARS), Raichur of N-E Karnataka during 2012-13 and 2013-14 to examine productivity, economic structure, employment generation, nutritional value addition and resource recycling.
\end{abstract}

KEY WORDS...... Backyard (free range) poultry rearing, Battery cage rearing, Marginal/ small farmers, Productivity, Economics, Employment, Livelihood/ nutritional security

HOW TO CITE THIS ARTICLE - Vinodakumar, S.N. and Desai, B.K. (2017). Poultry farming : Suitable intervention for livelihood support and nutritional security of marginal/small farmers of N-E Karnataka. Asian J. Animal Sci., 12(1): 43-48. DOI : 10.15740/HAS/TAJAS/12.1/43-48.

ARTICLE CHRONICLE - Received : 03.04.2017; Revised : 09.05.2017; Accepted : 22.05.2017 